\title{
PENGEMBANGAN SISTEM DISKON UNTUK PEMBELI KAIN DENGAN MEMPERTIMBANGKAN KONSEP WAKTU NILAI UANG: STUDI KASUS
}

\author{
Novitria Arie Prabarini ${ }^{1)}$ dan Wahyudi Sutopo ${ }^{2)}$ \\ ${ }^{1)}$ Mahasiswa Jurusan Teknik Industri, Universitas Sebelas Maret \\ ${ }^{2)}$ Laboraturium Sistem Logistik dan Bisnis, Jurusan Teknik Industri, Universitas Sebelas Maret \\ Jl. Ir. Sutami No. 36 A, Surakarta 57126, Indonesia \\ novitria.prabarini@gmail.com, wahyudisutopo@gmail.com
}

\begin{abstract}
Abstrak
PT XYZ adalah suatu perusahaan tekstil yang memproduksi dan menjual kain grey. Dari data dua tahun terakhir, perusahaan memiliki masalah dalam memenuhi permintaan pembeli dan telah mengalami kehilangan kesempatan penjualan hingga 9\%. Masalah tersebut dapat mengakibatkan kepercayaan pelanggan semakin menurun, bahkan perusahaan dapat kehilangan pembeli. Perkembangan bisnis fashion secara pesat diduga mempengaruhi volume permintaan. Pengembangan sistem diskon yang tepat berdasarkan waktu pemesanan dapat mendorong pembeli untuk lebih cepat dalam melakukan pemesanan sehingga perusahaan dapat menyusun rencana produksi dengan baik. Pada penelitian ini telah dikembangan sistem diskon melalui tiga langkah, yaitu: identifikasi faktor yang dipertimbangkan oleh pembeli dalam mengambil keputusan pemesanan; formulasi diskon yang mempertimbangkan nilai waktu dari uang (time value of money); dan prosedur operasi standar sebagai dasar perusahaan mengimplementasikan sistem diskon yang diusulkan. Dari hasil contoh numerik dapat ditunjukkan bahwa sistem usulan dapat digunakan perusahaan mendorong pembeli memesan lebih awal, rencana produksi dapat disusun lebih cepat, dan pemenuhan permintaan dapat dilakukan lebih baik sehingga hubungan pemasok-pembeli dapat lebih baik.
\end{abstract}

Kata kunci: hubungan pemasok-pembeli, nilai waktu dari uang, prosedur operasi standar, sistem diskon

\begin{abstract}
XYZ Ltd. is a company which manufactures and sells textile gray fabric. Data from the last two years, the company has problems in fulfilling the demand of buyers and have experienced lost sales opportunities up to 9\%. The problem can result in decreased customer confidence, even the company may lose buyers. The rapid development of the fashion business is expected to affect the volume of demand. The development of appropriate discount system based on the appropriate ordering time can encourage buyers to more quickly in an order so that the company can plan production well. In this study, the system has cultivated a discount through three steps, namely: identification of the factors considered by the buyer in making a decision ordering; discounts formulation that considers the time value of money, and standard operating procedures as a basis for implementing the company's discount system proposed. From the numerical example results. It can be shown that the proposed system can be used by company to encourage buyers to order early, the production plan can be developed more quickly, and the order fulfillment can be improved so that the supplier-buyer relationship can be enhanced.
\end{abstract}

Keywords: supplier-buyer relationship, time value of money, standard operating procedures, discount system

\section{PENDAHULUAN}

Perusahaan PT. XYZ merupakan perusahaan tekstil yang memproduksi kain grey. Berdasarkan observasi selama 1 bulan diperoleh data melalui wawancara bahwa dalam 6 bulan terakhir perusahaan mengalami peningkatan jumlah pesanan yang cukup signifikan hingga melebihi kapasitas produksi. Selain itu, dari analisis data pesanan masa lalu diketahui bahwa perusahaan mengalami kehilangan kesempatan penjualan hingga $9 \%$ dalam kurun waktu dua tahun terakhir. Bagi perusahaan hal tersebut sangat tidak menguntungkan, karena jika penolakan tersebut terus dilakukan maka akan 
menurunkan kepercayaan pelanggan. Perkembangan bisnis fashion secara pesat diduga mempengaruhi peningkatan volume permintaan. Perusahaan XYZ tidak mampu memenuhi permintaan buyer yang memesan dalam jumlah yang besar dengan waktu kontrak yang singkat. Agar pesanan semua buyer dapat terpenuhi, maka perlu dirancang sistem diskon sebagai kebijakan perusahaan supaya mampu menjaga pembelinya.

Diskon merupakan potongan harga yang diiberikan oleh penjual kepada pembeli (Kotler, 2000). Diskon adalah pengurangan harga produk dari harga normal dalam periode tertentu (Sutisna, 2001). Faktor yang menyebabkan perusahaan memberikan diskon yaitu konsumen membayar lebih cepat dari waktu yang telah ditentukan, pembelian dalam jumlah besar, adanya perbedaan timbangan (Alma, 2000).Fungsi potongan harga antara lain meningkatkan volume penjualan, memenagkan persaingan, mengurangi stock barang, memperkuat merek, mempercepat memperoleh uang kas, sarana penunjang promosi produk, dan mengatur volume produksi (Kotler, 2000). Terdapat berbagai jenis diskon antara lain cash discount, quantity discount, bonus agreement, geographical discount, seasonal discount, promotional discount, dan trade discount (Mc Carthy dan Jerome, 2005) dan (Rangkuti, 2005). Perusahaan harus menetapkan model diskon yang sesuai dengan kondisi perusahaan dengan buyer, supaya model diskon dapat diterapkan secara efektif. Time value of money atau dalam bahasa Indonesia disebut nilai waktu uang merupakan suatu konsep yang menyatakan bahwa nilai uang sekarang akan lebih berharga dari pada nilai uang masa yang akan datang atau suatu konsep yang mengacu pada perbedaan nilai uang yang disebabkan karena perbedaan waktu (Pujawan, 2008). Konsep ini sangat mendasar karena nilai uang akan berubah menurut waktu yang disebabkan banyak faktor yang mempengaruhinya.

Perancangan model diskon yang dipilih mengacu pada paper Wang and Wu (Wang and $\mathrm{Wu}, 2000$ ). Namun pada model tersebut belum dikembangan berdasarkan waktu dan hanya berdasarkan quantity saja. Maka dalam paper ini mencoba melakukan perancangan model diskon tersebut berdasarkan waktu dengan pendekatan konsep time value of money yang hasilnya akan dijadikan SOP dalam penetapan harga. SOP (Standard Operation Procedure) merupakan suatu acuan atau pedoman tertulis yang digunakan untuk melaksanakan atau menyelesaikan suatu proses kerja tertentu untuk menjamin standar mutu hasil pekerjaan (Mustafa, B). SOP yang dihasilkan berupa harga setelah diskon dan waktu pesan. Dengan adanya SOP perusahaan dapat meminimalkan lost sales sehingga dapat meningkatkan kepercayaan antara buyer-supplier.

\section{METODE PENELITIAN}

Penelitian ini dilakukan dengan mengembangkan model matematik untuk diskon yang telah ada. Kajian yang dilakukan merupakan upaya investigasi yang teroganisir, sistematis, objektif, dan ilmiah. Berikut framework metode penelitian yang dilakukan.

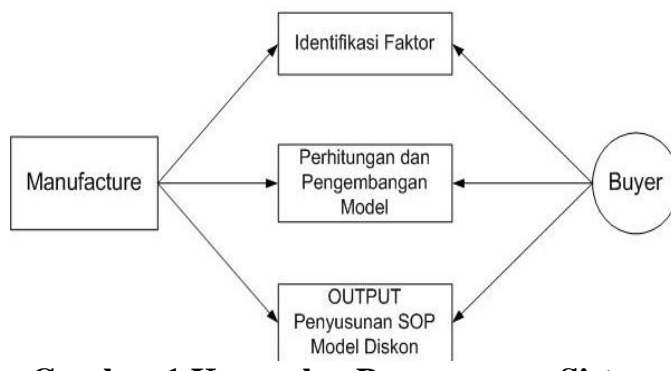

Gambar 1 Kerangka Perancangan Sistem Diskon

Terdapat 3 tahap dalam melakukan perancangan model diskon yang akan ditetapkan perusahan PT. XYZ. Langkah pertama yaitu mengidentifikasi faktor yang dipertimbangkan supplier dalam mengambil keputusan mengenai diskon. Faktor-faktor tersebut diidentifikasi berdasarkan masalah utama yang terjadi di level taktikal yaitu hubungan antara buyer-supplier. Faktorfaktor yang dipertimbangkan antara lain jumlah demand, kapasitas produksi, dan waktu kontrak. Langkah kedua yaitu melakukan pengembangan model dengan pendekatan time value of money melalui perhitungan rumus diskon yang telah 
dipilih yaitu model quantity diskon pada paper Wang dan Wu (Wang dan Wu, 2000). Model tersebut dipilih karena model tersebut membantu untuk memperoleh presentase diskon dengan quantity tertentu, sedangkan quantity pada kasus ini sudah diasumsikan, sehingga model lebih mudah diterapkan dan dikembangkan. Langkah ketiga memberikan usulan standard operation procedure (SOP) sebagai dasar perusahaan mengimplementasikan sistem usulan.

\section{PENGEMBANGAN MODEL}

Masalah yang dihadapi yaitu bagaimana perusahaan menetapkan kebijakan diskon untuk setiap buyer berdasarkan waktu kontrak. Dalam penyusunan sistem diskon diperlukan input data berupa biaya simpan $(h)$ dan biaya pemenuhan order $(A)$ (Sari, 2013). Biaya simpan merupakan biaya yang timbul akibat adanya aktivitas penyimpanan produk di gudang. Komponen biaya simpan antara lain capital cost, storage and space cost, inventory service cost, dan risk cost (Sari, 2013). Komponen biaya pemenuhan order terdiri atas biaya transportasi, biaya perawatan, biaya pajak (Sari, 2013). Pada khasus ini asumsi yang digunakan yaitu quantity tiap order sebesar 918.000 $\mathrm{m} /$ bulan/buyer, bunga $12 \%$ per tahun, $\alpha=$ $100 \%$ karena selalu/pasti order sebanyak $918.000 \mathrm{~m}$. Pada perhitungan quantity diskon demand tidak dipengaruhi oleh diskon dari supplier dan lead time 0. Selain itu untuk biaya pesan, simpan, dan EOQ setiap buyer sama.

\section{Parameter dan Variabel}

Berikut notasi rumus yang akan digunakan dalam perhitungan.

$\mathrm{P} \quad$ : harga/meter sebelum diskon

$\mathrm{m}$ : jumlah buyer , $\mathrm{i}=1,2 \ldots, \mathrm{m}$

$\mathrm{D}_{\mathrm{i}} \quad$ : annual quantity demand

$\mathrm{A}_{\mathrm{i}} \quad$ : biaya pesan buyer per order

$\mathrm{A}_{\mathrm{si}}$ : biaya supplier untuk melakukan pemenuhan order ke buyer

$h_{i} \quad$ : biaya simpan buyer per unit order

$\mathrm{h}_{\mathrm{s}} \quad$ : biaya simpan supplier per unit order, $h_{s}<h_{i}$

$$
\begin{array}{ll}
\mathrm{Q}_{\mathrm{i}} & : \text { EOQ buyer, } \quad \sqrt{\frac{2 \mathrm{D}_{\mathrm{i}} \mathrm{A}_{\mathrm{i}}}{\mathrm{h}_{\mathrm{i}}}} \\
\rho & : \% \text { diskon } \\
\alpha & : \% \text { jumlah order } \\
\mathrm{F} & : \text { harga setelah diskon } \\
\mathrm{i} & : \text { tingkat bunga } \\
\mathrm{n}_{\mathrm{j}} & : \text { minggu ke-j, } \mathrm{j}=1,2,3 \ldots 4
\end{array}
$$

\begin{tabular}{|c|c|c|c|c|c|c|}
\hline Buyer & $D i$ & hi & Ai & Asi & $Q i$ & $\theta i$ \\
\hline 1 & 918,000 & 1,500 & 6,000 & 5,000 & 2,710 & 361 \\
\hline 2 & 918,000 & 1,500 & 6,000 & 5,000 & 2,710 & 361 \\
\hline 3 & 918,000 & 1,500 & 6,000 & 5,000 & 2,710 & 361 \\
\hline
\end{tabular}

Tabel 1 Contoh data yang diperoleh dari perusahaan

2. Model Quantity Discount Wang dan Wu

Pada model Wang dan Wu menunjukan model untuk mencari jumlah maksimal order dan kuantitas \% diskonnya berdasarkan kenaikan order oleh buyer.

Pertama, Model ini dapat memberikan keuntungan maksimum baik antara supplier dan buyer. Model diskon wang dan wu disusun berdasarkan prosentase kenaikan quantity order.

Kedua, dengan model ini dapat meningkatkan jumlah pembelian yang dilakukan oleh buyer. Terutama apabila terdapat beberapa buyer yang memesan dengan jumlah yang bervariasi.

Ketiga, model ini menguntungkan bagi kedua pihak karena bila buyer memesan dalam jumlah yang semakin banyak, maka ia akan mendapatkan diskon yang semakin tinggi pula, begitu juga sebaliknya. Disisi buyer, ia akan secara cepat mengganti siklus produknya, atau dapat menghabiskan stok.

Fungsi Tujuan:

$$
\operatorname{Max}_{\alpha_{i} \rho_{i}}: \sum_{i=1}^{m}\left(-D_{i} \rho_{i} P+\frac{D_{i}}{Q_{i}} \frac{\alpha_{i}}{1+\alpha_{i}} A_{s i}+\frac{1}{2} Q_{i} h_{s} \alpha_{i}\right)
$$

Pembatas:

$$
-\theta\left(\rho_{i}-\rho_{i-1}\right)+\frac{1}{1+a_{i}}+a_{i}-\frac{1}{1+a_{i-1}}-a_{i-1}=0, i=1, \ldots \ldots, \ldots ;
$$




$$
\begin{aligned}
& \alpha_{i-1}-\alpha_{i} \leq 0, \quad i=1, \ldots, m ; \\
& F_{i}\left(\alpha_{i}, \rho_{i}\right), \alpha_{i} \text { and } \rho_{1} \geq 1, i=1, \ldots, m ; \\
& \mathrm{F}_{\mathrm{i}}=\left(\alpha_{\mathrm{i}}, \rho_{\mathrm{i}}\right) \\
& =\mathrm{F}_{\mathrm{i}}\left(\alpha_{\mathrm{i}-1}, \rho_{\mathrm{i}-1}\right) \\
& \rho_{\mathrm{i}-1} \leq \rho_{\mathrm{i}}
\end{aligned}
$$

\section{Pengembangan Model dengan pendekatan Time Value of Money}

Pada paper ini akan dikembangkan model diskon dengan pendekatan konsep time value of money dengan menentukan future value. Future value $(F)$ merupakan nilai uang yang akan datang berdasarkan suku bunga pada periode tertentu (Dada dan Srikanth, 1987).

Setelah mendapatkan jumlah order dan $\%$ diskon $(\rho)$ maksimalnya (persamaan 1) untuk quantity (D), maka harga setelah diskon untuk minggu (n) ke dapat dihitung melalui persamaan:

$$
F=(1-\rho) \cdot P(1+i)^{n}
$$

Dari persamaan tersebut dapat diketahui seberapa besar diskon setiap minggunya. Pada model tersebut berlaku untuk $\mathrm{n}=1$ sampai 8 minggu masa order. Bila buyer melakukan order diawal minggu, maka harga akan semakin murah.

\section{HASIL DAN PEMBAHASAN}

\section{Hasil Identifikasi Faktor}

Terkait riset yang telah dilakukan oleh Sari (2013), Wang dan Wu (2000), Dada dan Srinkanth (1987) mengenai pengaruh penjualan terhadap faktor diskon dapat disimpulkan melalui wawancara. Hasil yang diperoleh yaitu adanya masalah pada level taktikal terutama pada hubungan buyer supplier. Pada level ini diperoleh data wawancara berupa

Kapasitas produksi $: 2.500 .000 \mathrm{~m} / \mathrm{bulan}$ Demand : $3.500 .000 \mathrm{~m} / \mathrm{bulan}$

Waktu penyelesaian : 2 bulan

Harga bahan baku : Rp. 3000,- / m Biaya Tenaga : Rp. 900.000,-/ bulan Jumlah ini tentu sangat sulit untuk dipenuhi oleh perusahaan, mengingat kapasitas yang dimiliki terbatas. Dari perhitungan jumlah demand diperoleh permintaan 1 buyer/bulan adalah sebesar $583.000 \mathrm{~m}$, permintaan tiba-tiba per bulan adalah sebesar $333.000 \mathrm{~m} /$ buyer. Maka jumlah demand/buyer/bulan adalah sebesar $918.000 \mathrm{~m}$, demand pada satu bulan adalah sebesar $2.754 .000 \mathrm{~m}$. Sehingga perusahaan akan lost sales sebesar 9\% per bulan. Dapat disimpulkan perlu ada pengaturan jumlah pesanan supaya pesanan dapat terpenuhi.

\section{Hasil Perhitungan}

dan

\section{Pengembangan Model}

Setelah mengidentifikasi masalah, maka berdasarkan masalah waktu dan quantity sebagai parameter, maka pendekatan yang sesuai yaitu menggunakan persamaan quantity order pada paper Wang dan Wu (2000). Variabel keputusan pada model wang dan wu yaitu jumlah maksimal order dan diskon yang dapat diberikan oleh supplier kepada buyer. Persentase (\%) diskon tersebut dapat berubah sesuai dengan persentase (\%) kenaikan jumlah order.

Untuk pengembangan model dari model wang dan wu, penelitian ini mengasumsikan jumlah maksimal order yaitu 981.000 untuk tiap buyer, karena model wang dan wu tersebut hanya digunakan untuk mencari \% diskon saja. Dengan menggunakan data yang ada bagian identifikasi faktor diatas diperoleh nilai sebagai berikut:

$\rho_{i} \quad=0.017=1.7 \%$

$F_{n}=(1-\rho) \cdot P(1+i)^{n}$

$F_{n}=$ ming gu ke $1, \ldots 8$

Perhitungan :

$F_{1}=(1-0.017)(8000)(1+0.002)^{1}$

$F_{1}=7.879,73$

Selain itu analisis waktu order juga mempengaruhi harga bahan baku dan biaya tenaga kerja. Hubungan bahan baku dengan waktu order dan tenaga kerja dianalisa dengan metode regresi liner yaitu melalui software SPSS. Dimana :

$\mathrm{Y}=\mathrm{a}+\mathrm{bX}$ 
Keterangan:

Y : Variabel dependen (nilai yang diprediksikan)

$\mathrm{X}$ : Variabel independen

a : Konstanta

b : Koefisien regresi

Hasil yang diperoleh dari regresi linier adalah :

- Biaya Tenaga kerja dengan waktu $\mathrm{Y}=-3.950+6250 \mathrm{X}$

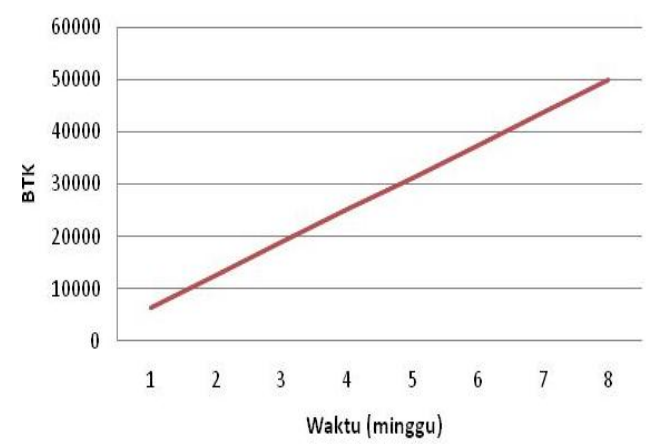

Gambar 2 Grafik hubungan Biaya Tenaga Kerja dengan Waktu

- Biaya Bahan Baku dengan Waktu $\mathrm{Y}=2750+250 \mathrm{X}$

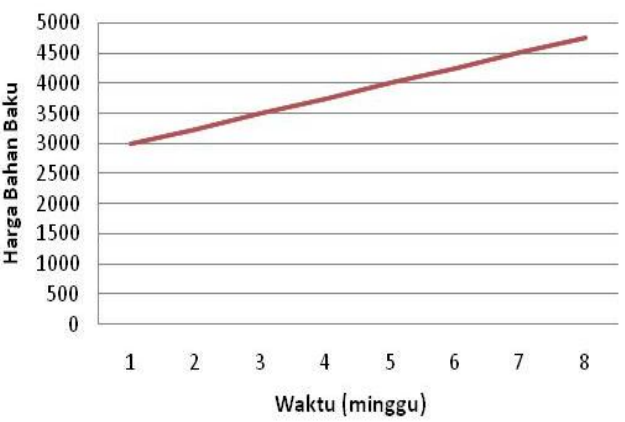

Gambar 3 Grafik hubungan Biaya Bahan Baku dengan Waktu

\section{Hasil Penyusunan SOP Sistem} Diskon

Standar Operasional Prosedur dapat disusun berdasarkan perhitungan model matematika yang telah dibuat. Input dari penyususnan SOP sistem diskon antara lain jumlah permintaan, time order, dan delivery time. Output yang dihasilkan berupa tabel yang terdiri dari interval waktu order dan harga.

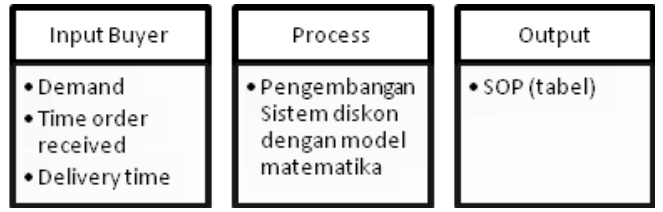

Gambar 4 Konsep Penyusunan SOP

Dari hasil perhitungan pada persamaan (5) dan (6) akan diperoleh diskon sebesar $1,7 \%$ untuk quantity 981.000 m. Harga setelah diskon untuk setiap interval waktu yakni dalam minggu dapat dihitung dengan persamaan (7) dan disajikan pada Tabel 2.

Tabel 2 Daftar Harga berdasarkan Waktu Pemesanan

\begin{tabular}{ccc}
\hline \multicolumn{3}{c}{ SOP SISTEM DISKON } \\
\hline \multicolumn{3}{c}{ QTY = 918.000 m/buyer order } \\
\hline No & $\begin{array}{c}\text { Waktu order } \\
\text { (Minggu ke) }\end{array}$ & Harga/m \\
\hline 1 & -8 & $7,879.73$ \\
2 & -7 & $7,895.49$ \\
3 & -6 & $7,911.28$ \\
4 & -5 & $7,927.10$ \\
5 & -4 & $7,942.96$ \\
6 & -3 & $7,958.84$ \\
7 & -2 & $7,974.76$ \\
8 & -1 & $7,990.71$ \\
\hline
\end{tabular}

SOP yang telah dibuat tersebut dapat digunakan oleh perusahaan sebagai tools untuk melakukan negoisasi kepada buyer. Dengan SOP ini, perusahaan dapat merencanakan pemberian diskon kepada buyer berdasarkan waktu kontrak. Diharapkan perusahaan dapat lebih baik dalam melakukan perencanaan produksi dan mengurangi jumlah lost order.

Waktu order juga mempengaruhi biaya tenaga kerja dan biaya bahan baku. Pada perhitungan dapat dianalisis bila waktu order semakin dekat, maka harga bahan baku dan biaya tenaga kerja akan semakin tinggi. 


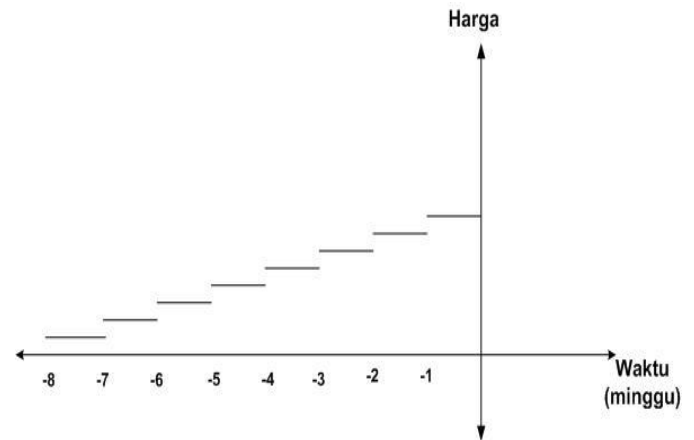

Gambar 4 Kurta Harga Menurut Waktu Pemesanan

Gambar 4 menunjukkan bahwa semakin dekat buyer melakukan order kepada supplier maka harga kain per meter juga semakin tinggi. Kebijakan ini di usulkan supaya pihak buyer dapat lebih cermat dalam melakukan pemesanan dengan kata lain buyer akan mendapat keuntungan jika memesan jauh hari sebelum deadline, karena akan mendapat harga murah. Perbedaan dengan kondisi saat belum dilakukan sistem diskon yaitu perusahaan mengalami lost sales sebesar 9\%, sedangkan pada model diskon yang diusulkan, dipastikan perusahaan tidak akan kehilangan order atau lost sales sebesar 0\%, namun ini akan meningkatkan kapasitas produksi serta biaya bahan baku dan tenaga kerja.

\section{KESIMPULAN}

Pengembangan sistem diskon yang diusulkan dapat digunakan perusahaan untuk mendorong pembeli memesan lebih awal, menyusun rencana produksi lebih cepat, dan memperbaiki tingkat pemenuhan permintaan. Sistem yang diusulkan menjadikan hubungan pemasok-pembeli dapat lebih baik karena member manfaat kepada kedua pihak. Perusahaan mendapatkan keuntungan yaitu dapat merencanakan volume dan kapasitas produksi dengan baik sehingga order yang diterima dapat diselesaikan secara tepat. Selain itu, pembeli mendapatkan manfaat yaitu harga murah dengan demikian pembelidapat melakukan penghematan pengadaan bahan baku.

\section{DAFTAR PUSTAKA}

1. Kotler, P., (2000). Manajemen Pemasaran di Indonesia, Penerbit Salemba Empat, Jakarta.

2. Sutisna (2001). Perilaku Konsumen dan Komunikasi Pemasaran, P Rosda, Jakarta.

3. Mc Carthy and Jerome, E., (2005). Dasar-Dasar Pemasaran (Edisi Bahasa Indonesia), Penerbit Erlangga, Jakarta.

4. Rangkuti, F. (2005). Riset Pemasaran, Penerbit PT Gramedia Pustaka Utama, Jakarta.

5. Pujawan, I. N. (2008). Ekonomi Teknik. Cetakan Ketiga. Surabaya: Guna Widya

6. Wang, Q. dan Wu, Z. (2000). "Improving a supplier quantity discount gain from many different buyers", IIE Transaction Journal. Vol. 32. pp. 10711079.

7. Mustafa, B. "Memenuhi harapan pengguna tentang layanan prima perpustakaan melalui penerapan SOP digital", Jurnal Pustakawan Indonesia. Vol .7.no.1

8. Sari, A. A, Yuniaristanto dan Sutopo, W. (2013), Perancangan Sistem Pemilihan Model Diskon untuk Buyer Produk Textile PT ABC dengan Pendekatan AHP, Jurn@l Teknik Industri, (ISSN:1907-1434), Vol VIII, No 1, Jan. 2013, pp. 51-58.

9. Alma, B. (2000). Manajemen Pemasaran dan Pemasaran Jasa, Cetakan keenam, Alfabeta, Bandung.

10. Dada, M. dan Srikanth, K.N. (1987) "Pricing policies for quantity discounts." Management Science, 33(10), 1247-1452. 